\title{
Cyclodextrins as Catalysts for the Removal of Cholesterol from Macrophage Foam Cells
}

\author{
Veronique M. Atger, ${ }^{\star}$ Margarita de la Llera Moya, ${ }^{\ddagger}$ Genevieve W. Stoudt, ${ }^{\ddagger}$ Wendi V. Rodrigueza, ${ }^{\ddagger}$ Michael C. Phillips, ${ }^{\ddagger}$ \\ and George H. Rothblat ${ }^{\ddagger}$ \\ *Hôpital Broussais, 75674 Paris, France; and $\ddagger$ Department of Biochemistry, Allegheny University of the Health Sciences, Philadelphia, \\ Pennsylvania 19129
}

\begin{abstract}
Low concentrations of cyclodextrins $(<1.0 \mathrm{mM})$ added to serum act catalytically, accelerating the exchange of cholesterol between cells and lipoproteins. J774 macrophages incubated with serum and 2-hydroxypropyl- $\beta$-cyclodextrin $(\leq 1 \mathrm{mM}$ ) released fivefold more labeled cholesterol than with serum alone. Increased efflux was not accompanied by a change in cell cholesterol mass; thus, cyclodextrin functioned as a cholesterol shuttle, enhancing cholesterol bidirectional flux without changing the equilibrium cholesterol distribution between cells and medium. The addition of phospholipid vesicles to serum and cyclodextrin shifted the equilibrium distribution to favor the medium, producing rapid and extensive depletion of cell cholesterol mass. The combination of serum, phospholipid vesicles, and cyclodextrin also stimulated the rapid clearance of both free and esterified cholesterol from mouse peritoneal macrophages loaded with free and esterified cholesterol. This study: (a) demonstrates that a compound can function as a catalyst to enhance the movement of cholesterol between cells and serum, $(b)$ illustrates the difference between cholesterol exchange and net transport in a cell/serum system, (c) demonstrates how net movement of cholesterol is linked to concentration gradients established by phospholipids, $(d)$ provides a basis for the development of the shuttle/sink model for the first steps in reverse cholesterol transport, $(e)$ validates the model using artificial shuttles (cyclodextrins) and sinks (large unilamellar vesicles), and $(f)$ suggests that cyclodextrin-like cholesterol shuttles might be of pharmacological significance in treating unstable atherosclerotic plaques. (J. Clin. Invest. 1997. 99:773-780.) Key words: cholesterol • cyclodextrins • foam cells • lipoproteins • serum
\end{abstract}

\section{Introduction}

The movement of cholesterol from cells to serum or interstitial fluid plays an important role in the maintenance of cellular cholesterol homeostasis and is thought to be the first step in

Address correspondence to George Rothblat, Department of Biochemistry, MCP Hahnemann Medical School, Allegheny University, 2900 Queen Lane, Philadelphia, PA 19129. Phone: 215-991-8308; FAX: 215-843-8849.

Received for publication 12 August 1996 and accepted in revised form 5 December 1996.

J. Clin. Invest.

(C) The American Society for Clinical Investigation, Inc.

0021-9738/97/02/0773/08 \$2.00

Volume 99, Number 4, February 1997, 773-780 the transport of peripheral tissue cholesterol back to the liver for excretion. This process, known as reverse cholesterol transport, is thought to be mediated primarily through the action of high density lipoprotein coupled with serum enzymes such as cholesteryl ester transfer protein and lecithin cholesterol acyltransferase $\left(\operatorname{LCAT}^{1}(1,2)\right.$. It has been proposed that this reverse cholesterol transport function of HDL imparts its protective effects against the development of atherosclerosis. It has been demonstrated that the movement of cholesterol molecules from the cell plasma membrane to the acceptor lipoprotein involves an aqueous diffusion mechanism in which the cholesterol molecule desorbs from the membrane and is incorporated into the acceptor after traversing the intervening aqueous phase. This movement is a function of the cholesterol gradient established between the plasma membrane and the phospholipid in the lipoprotein acceptors. Since serum lipoproteins contain unesterified cholesterol that exchanges between cells and the lipoprotein, the movement of cholesterol is a bidirectional process (i.e., influx and efflux) and net movement of cholesterol mass is determined by the relative contribution of both influx and efflux. Although the efflux step does not require specific binding of the HDL to the cell surface, there is evidence that the interaction of HDL with the cell membrane, either through specific receptors or through lipid domains, can mediate the translocation of internal pools of cell cholesterol to the plasma membrane $(3,4)$.

A variety of HDL subclasses have been implicated in cellular cholesterol efflux. Small, phospholipid-rich particles, characterized as pre $\beta$-HDL, have been proposed as the initial acceptors of cholesterol (5), whereas other larger HDL particles containing various combinations of apoproteins and lipids have been demonstrated to modulate the efflux of labeled cholesterol from cells and/or to modify cell cholesterol content (6). A general model for the function of the various HDL subclasses in cholesterol efflux is that small particles function as high efficiency intermediates (i.e., shuttles) that move cholesterol from the plasma membrane to larger HDL particles that serve as reservoirs ("sinks") where cholesterol is converted to cholesteryl ester $(1,2)$. Since the accumulation of cholesterol in the plaque is a hallmark of the atherosclerotic process, an obvious treatment goal would be to enhance the efficiency of HDL particles in removing cholesterol stored in the foam cells within the lesion. If the general model proposed above is correct, then the mobilization of tissue cholesterol might require an elevation of lipoproteins functioning as both shuttles and sinks to effectively enhance reverse cholesterol transport. In an effort to test the "shuttle-sink" model for cholesterol efflux,

1. Abbreviations used in this paper: $2 \mathrm{OH} \beta \mathrm{CD}, 2$-hydroxypropyl- $\beta$-cyclodextrin; ACAT, acyl cholesterol ester transferase; LCAT, lecithin cholesterol acyltransferase; LUV, large unilamellar vesicles. 
and to establish if this model could be of pharmacological importance, we have conducted studies in which cell cholesterol efflux to serum was quantitated when we supplemented serum with nonlipoprotein models of particles that could function as either cholesterol shuttles or sinks. For the potential shuttle, we used 2-hydroxypropylbetacyclodextrin (2OHßCD) (7). We have recently demonstrated that $\beta$-cyclodextrins, which are cyclic heptasaccharides consisting of $\beta(1-4)$-glucopyranose units, when present in the culture medium, have the ability to promote extensive release of cholesterol from a variety of cells in culture $(8,9)$. It was thus of interest to determine if cyclodextrins, when added to serum, would have the ability to enhance the efflux potential of serum, and stimulate the net removal of cell cholesterol. At the high cyclodextrin concentrations we have used in previous studies $(10-100 \mathrm{mM})$, the cyclodextrin can itself trap released cholesterol and serve as a sink $(8,9)$. Therefore, in the present studies we were interested in testing lower concentrations where the cyclodextrin might function as a high efficiency, low capacity transporter. As a model for lipoproteins that serve as cholesterol sinks, we have used large unilamellar vesicles (LUV) composed of egg phosphatidylcholine. We selected LUV as acceptors because such particles have been shown to effectively participate in the mobilization of tissue cholesterol when they are injected into mice (10). In addition, because of their relatively large size they are inefficient in stimulating cell cholesterol efflux (11), although they do have a high capacity to solubilize cholesterol.

\section{Methods}

Materials. Tissue culture flasks and plates were obtained from Falcon Labware (Lincoln, NJ) and Corning Glass Works (Corning, NY). Culture media was purchased from Mediatech, Inc. (Herndon, VA) and trypsin was obtained from Gibco Laboratories (Grand Island, NY). BSA (essentially fatty acid free), heat-inactivated FBS, cholesteryl methyl ether, and unesterified cholesterol were purchased from Sigma Chemical Co. (St. Louis, MO). 1-Palmitoyl-2-oleoyl phosphatidylcholine was purchased from Avanti Polar Lipids (Alabaster, AL). $\left[{ }^{3} \mathrm{H}\right]$ Cholesterol $(51 \mathrm{Ci} / \mathrm{mmol})$ was purchased from New England Nuclear (Boston, MA). All organic solvents were obtained from Fisher Scientific Co. (Pittsburgh, PA). Methyl- $\beta$-cyclodextrin and $\beta$-cyclodextrin were obtained from Sigma Chemical Co. All other cyclodextrins were purchased from Cyclodextrin Technologies Development, Inc. (Gainesville, FL). Concentrates of the cyclodextrins were made to $10 \mathrm{mM}$ in media and diluted to the indicated concentrations before use. Sandoz compound 58-035 was a gift from Dr. John Heider (Sandoz, East Hanover, NJ).

Cell culture. The J774 mouse macrophage cell line was grown in RPMI-1640 (Gibco Laboratories) supplemented with 10\% heat inactivated FCS as previously described (12). $3 \mathrm{~d}$ after the initial plating of stock cultures of cells in 22-mm wells, the cells were enriched with cholesterol and labeled with $\left[{ }^{3} \mathrm{H}\right]$ cholesterol by growing the monolayers for $2 \mathrm{~d}$ in $2 \mathrm{ml}$ medium supplemented with $1 \%$ FBS, $50 \mu \mathrm{g} / \mathrm{ml}$ acetyl LDL protein $(12,13)$ and $1 \mu \mathrm{Ci} / \mathrm{ml}\left[1,2-{ }^{3} \mathrm{H}\right]$ cholesterol. In a number of experiments, Sandoz compound 58-035 was added $(1 \mu \mathrm{g} /$ $\mathrm{ml}$ ) to block the acyl cholesterol ester transferase (ACAT) reaction and load the cells with only free cholesterol (14). When the ACAT inhibitor was omitted, the cells were enriched with both free and esterified cholesterol. After the loading/labeling period, the cells were incubated for an additional 18-24 h in medium supplemented with $0.2 \%$ bovine serum albumin to allow the equilibration of labeled cholesterol among cellular pools and to allow the incorporation of surface bound lipoproteins. Elicited mouse peritoneal macrophages were isolated from B6C3F1 (Taconic Farms, Germantown, NY) mice and maintained in culture using previously published protocols (15). The monolayers in 22-mm wells were labeled and loaded with cholesterol, and equilibrated in BSA as described above for the J774 cells, except that the ACAT inhibitor was omitted and the cells accumulated both free and esterified cholesterol.

Human sera and LUV. Because it was observed that some specimens of human serum were toxic to $\mathrm{J} 774$ cells and produced some cell toxicity during prolonged incubations, samples of sera from a number of normal volunteers were first screened to select those sera that did not affect the cells. The toxicity of some specimens of human serum for mouse cells in culture has been attributed to the presence of heterophile antibodies $(16,17)$. Blood was collected from the selected donors (with informed consent), clotted for $1 \mathrm{~h}$ at room temperature, pooled, and frozen at $-70^{\circ} \mathrm{C}$ as previously described (6).

To prepare LUV (9), lipids from stock solutions were mixed in the desired proportions in a test tube, and the solvent was removed first under a stream of nitrogen $\left(\mathrm{N}_{2}\right)$, and then by placing the tube under high vacuum for $2 \mathrm{~h}$. The dry lipid was hydrated at $55^{\circ} \mathrm{C}$ for 10

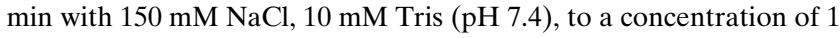
$\mathrm{mM}$ total lipid, and then vortexed to generate multilamellar vesicles. LUV were prepared from multilamellar vesicles by extrusion through two stacked polycarbonate filters of $0.1-\mu \mathrm{m}$ diameter using a waterjacketed thermobarrel extruder (Lipex Biomembranes, Vancouver, Canada) equilibrated at $55^{\circ} \mathrm{C}$.

Measurement of cholesterol efflux. The efflux experiments were initiated when the labeled cell monolayers were washed three times with PBS, and $2 \mathrm{ml}$ of medium containing the indicated acceptors were added to each well. Efflux was measured on cells maintained in a shaking waterbath $(40 \mathrm{rpm})$ at $37^{\circ} \mathrm{C}$, and $100-\mu \mathrm{l}$ aliquots were taken to monitor efflux at indicated times. These samples were filtered through $0.45-\mu \mathrm{m}$ Multiscreen (96 screens) filtration plates (Millipore Corp., Bedford, MA), and 75- $\mu$ l aliquots were then counted to determine the release of labeled cholesterol from the cells. Fractional efflux values were calculated as previously described $(8,9,11)$. Briefly, the percentage of the radiolabeled cholesterol that was released was calculated by dividing the total amount of $\left[{ }^{3} \mathrm{H}\right]$ cholesterol in the incubation medium at each sampling time by the total $\left[{ }^{3} \mathrm{H}\right]$ cholesterol in the cells at time zero. Cell monolayers (before and after the incubation with acceptors) were rinsed three times with PBS, and the cell lipids were then extracted by incubating the dried monolayers in $2 \mathrm{ml}$ of isopropanol at room temperature overnight. The cholesterol content was quantified by the procedure of Ishikawa et al. (18) as modified by Klansek et al. (19) using cholesteryl methyl ether as an internal standard. An extra set of cells was harvested at the beginning of the efflux period to determine initial cellular $\left[{ }^{3} \mathrm{H}\right]$ cholesterol and cholesterol mass. At the end of the indicated incubation periods, all of the $\left[{ }^{3} \mathrm{H}\right]$ cholesterol remaining in the treated cells was present as unesterified cholesterol. Cell protein was determined on the remaining monolayer using a modification of the method of Markwell et al. (20). Cell protein was dissolved in a solution of $0.1 \mathrm{~N} \mathrm{NaOH}$ and $1 \%$ SDS, and duplicate aliquots were taken out for protein determinations (13). Thin layer chromatography for the separation of free and esterified cholesterol was conducted as previously described (13). We observed no evidence of cell toxicity during the incubation of the monolayers with the cyclodextrins.

Efflux was calculated from the fraction of initial $\left[{ }^{3} \mathrm{H}\right]$ cholesterol, or cholesterol mass, remaining in the cells at each time point. For time-course experiments, these data were fitted to a single exponential model using nonlinear regression as previously described (21). The nonparametric Mann-Whitney test was used to compare treatments.

\section{Results}

Efflux to serum supplemented with $2 O H \beta C D$ and/or LUV. The general approach in these investigations was to quantitate both the efflux of labeled cholesterol and the change in cell cholesterol mass. Fig. $1 A$ shows the results of an experiment in which $\mathrm{J} 774$ macrophages that had been enriched in $\left[{ }^{3} \mathrm{H}\right]$ cholesterol were exposed to $5 \%$ human serum, or $5 \%$ serum supple- 

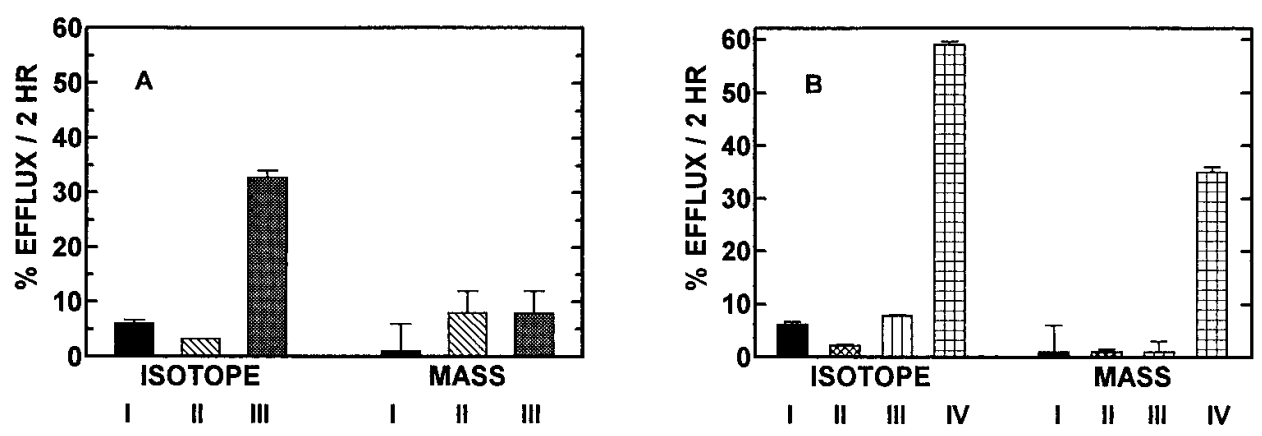

Figure 1. Efflux of cholesterol from $\mathrm{J} 774$ cells exposed to combinations of human serum, LUV, and 2OHßCD. J774 macrophages grown in 22-mm wells were enriched in $\left[{ }^{3} \mathrm{H}\right]$ cholesterol by growth for $3 \mathrm{~d}$ in $2 \mathrm{ml}$ MEM supplemented with acetyl LDL (50 $\mu \mathrm{g}$ protein $/ \mathrm{ml}$, $1 \mu \mathrm{Ci} / \mathrm{ml}\left[{ }^{3} \mathrm{H}\right]$ cholesterol). The

ACAT inhibitor Sandoz compound 58-035 was present during loading and equilibration periods to insure that all cell cholesterol was present as free cholesterol (time 0 cholesterol $=103 \pm 1 \mu \mathrm{g} / \mathrm{mg}$ cell protein). After an 18 to $24 \mathrm{~h}$ equilibration period during which monolayers were exposed to MEM plus $0.2 \%$ bovine serum albumin, the monolayers were washed. At this time, cell lipids were extracted with isopropanol from time 0 monolayers to obtain initial values for cellular cholesterol isotope and mass. The remaining monolayers were exposed to MEM supplemented with the indicated additions. After a 2-h incubation at $37^{\circ} \mathrm{C}$, the medium was removed and the monolayers were washed and the cell lipids extracted with isopropanol. The fractional release of labeled cholesterol was calculated by dividing the amount of radioactive cholesterol in the medium by the total radioactive cholesterol in time 0 cells. The mass of cell cholesterol was determined by gas chromatography and the fractional efflux of cell cholesterol mass was calculated from the change in mass between monolayers analyzed at time 0 and treated monolayers analyzed after a 2-h incubation. (A) Bar I, cells exposed to $5 \%$ human serum (HS); bar II, $1.5 \mathrm{mM} 2 \mathrm{OH} \beta \mathrm{CD}$; bar III, HS plus $1.5 \mathrm{mM} 2 \mathrm{OH} \beta C D$. $(B)$ Bar I, cells exposed to $5 \%$ HS; bar II, LUV at $1 \mathrm{mg} / \mathrm{ml}$ phospholipid; bar III, HS plus LUV; bar IV, HS plus LUV plus $1.5 \mathrm{mM} 2 \mathrm{OH} \beta C D$. All values are average and SD of triplicate determinations.

mented with $2 \mathrm{OH} \beta \mathrm{CD}$ or $2 \mathrm{OH} \beta \mathrm{CD}$ alone. The addition of the $2 \mathrm{OH} \beta \mathrm{CD}(1.5 \mathrm{mM})$ to the serum greatly stimulated the efflux of the labeled cholesterol after $2 \mathrm{~h}$ of incubation at $37^{\circ} \mathrm{C}$ (Fig. 1 A, ISOTOPE). However, the actual change in cell cholesterol mass was very small under all incubation conditions ( $\leq 10 \%$, Fig. $1 A, M A S S$ ). A similar pattern was obtained with 6-h incubations (data not shown). Thus, although the presence of $2 \mathrm{OH} \beta \mathrm{CD}$ greatly stimulated the release of label, it also enhanced the influx of unlabeled cholesterol from the serum lipoproteins. This accelerated exchange of cholesterol between cells and lipoprotein indicated that, at the concentrations of $2 \mathrm{OH} \beta \mathrm{CD}$ added, the cyclodextrin was acting as a shuttle moving cholesterol between cell membranes and lipoproteins without significantly changing the equilibrium distribution of cholesterol between cells and medium.

The inability of serum to stimulate the removal of cholesterol mass from $\mathbf{J} 774$ cells is consistent with previous studies indicating that net efflux of cholesterol from these cells only occurs when a large cholesterol gradient is established between cells and medium $(12,22)$. We have previously shown that the potential of individual samples of serum to stimulate efflux is closely linked to the phospholipid content of the serum lipoproteins, and it has been demonstrated that the addition of phospholipid to whole serum or serum lipoproteins can shift the equilibrium of the cholesterol gradient to favor the medium $(2,23,24)$. Thus, we investigated the effect on cell cholesterol efflux of the addition of LUV composed of egg phosphatidylcholine when these potential cholesterol acceptors were added to serum either alone or in combination with cyclodextrins.

The addition of LUV (1 $\mathrm{mg}$ phospholipid/ml), whether alone or in $5 \%$ serum, had very little effect on the efflux of labeled cell cholesterol (Fig. 1 B, ISOTOPE). However, the combination of $2 \mathrm{OH} \beta \mathrm{CD}(1.5 \mathrm{mM})$ and LUV greatly stimulated the release of labeled cholesterol at both the 2- and 6-h (data not shown) incubation times (Fig. $1 \mathrm{~B}, I S O T O P E$ ). An impressive reduction in cell free cholesterol mass was obtained when the combination of $2 \mathrm{OH} \beta \mathrm{CD}$ and LUV were added to serum, with 35 and $55 \%$ of the cell cholesterol being removed at 2 and $6 \mathrm{~h}$, respectively (Fig. $1 B, M A S S$ ). Thus, although the addition of cyclodextrins to serum stimulated the rate of exchange of cholesterol between cells and serum, only the combination of cyclodextrin and LUV shifted the equilibrium and produced net clearance within the time frame of these experiments. In addition, it should be noted that neither cyclodextrins nor LUV alone stimulated net cholesterol removal, only the combination was effective. From these results, it is apparent that the LUV are having very little impact on the rate of cholesterol movement, but are acting as an extracellular sink, and shifting the cell-medium cholesterol equilibrium to favor net efflux.

Effect of serum concentration on cholesterol efflux. To determine the extent to which the shuttle/sink model for cell cholesterol flux was influenced by the concentration of serum, an experiment was conducted in which free cholesterol-enriched J774 cells were exposed to increasing concentrations of human serum for $6 \mathrm{~h}$. The serum was added either alone or supplemented with LUV, $2 \mathrm{OH} \beta \mathrm{CD}$, or both LUV and $2 \mathrm{OH} \beta \mathrm{CD}$ (Fig. 2). Increasing concentrations of serum produced a modest increase in cell cholesterol content that was not influenced by the addition of $2 \mathrm{OH} \beta \mathrm{CD}$, even though the presence of $2 \mathrm{OH} \beta \mathrm{CD}$ greatly stimulated the release of labeled cell cholesterol at all serum concentrations (data not shown). Addition of LUV $(1 \mathrm{mg} / \mathrm{ml})$ to serum resulted in a modest depression of cell cholesterol content when compared with serum alone. The most dramatic change in cell cholesterol content occurred at all concentrations of serum when both $2 \mathrm{OH} \beta \mathrm{CD}$ and LUV were present, with reductions in cell cholesterol content ranging between 40 and $50 \%$ as compared with the human serum alone (Fig. 2). Since the concentration of serum did not affect the magnitude of the $2 \mathrm{OH} \beta \mathrm{CD} / \mathrm{LUV}$ response, $5 \%$ serum was used in subsequent experiments since at this level the concentration of lipoproteins, particularly HDL, would approximate that found in interstitial fluid (25). Also, 5\% serum has been used in a number of studies comparing the efflux potential of human and animal sera $(6,26)$. 


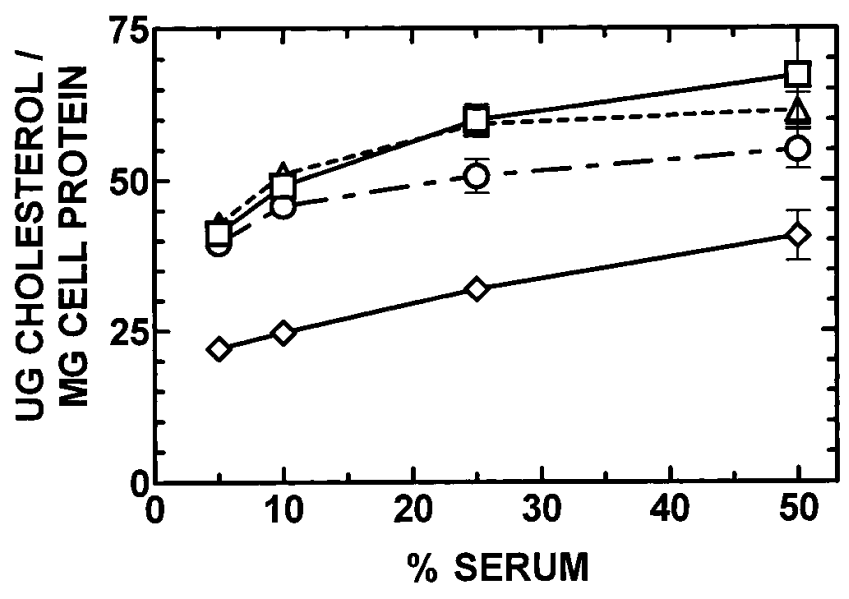

Figure 2. Effect of increasing serum concentration on the efflux of cholesterol when J774 cells were incubated with mixtures of human serum, LUV, and $2 \mathrm{OH} \beta \mathrm{CD}$. Monolayers of $\mathrm{J} 774$ cells were grown and enriched with free cholesterol as described in Fig. 1. After the equilibration period, the monolayers were incubated for $6 \mathrm{~h}$ with increasing concentrations of human serum (HS) either alone $\square$, or the same concentrations of HS together with $1.0 \mathrm{mM} 2 \mathrm{OH} \beta \mathrm{CD} \Delta$; HS plus LUV ( $1 \mathrm{mg} / \mathrm{ml}$ phospholipid) $\bigcirc$; or HS plus $2 \mathrm{OH} \beta \mathrm{CD}(1 \mathrm{mM})$ and LUV $(1 \mathrm{mg} / \mathrm{ml}$ phospholipid $) \diamond$. At the end of the incubation, the cholesterol contents of the cell monolayers were determined by gas-liquid chromatography. Cell cholesterol content at time $0=48.5 \pm 1.3 \mu \mathrm{g} / \mathrm{mg}$ protein. The values are the average and SD of triplicate determinations.

Influence of $2 O H \beta C D$ concentration on cholesterol efflux. The experiment presented in Fig. 3 was designed to establish the concentration of $2 \mathrm{OH} \beta \mathrm{CD}$ that, when added to serum containing LUV, functioned most efficiently as a cholesterol shuttle. Fig. $3 A$ illustrates that at concentrations $\leq 1 \mathrm{mM}$, $2 \mathrm{OH} \beta \mathrm{CD}$, when added in the absence of serum, did not stimulate the release of labeled cholesterol. Above $1 \mathrm{mM}$, the $2 \mathrm{OH} \beta \mathrm{CD}$ stimulated efflux by trapping the released cholesterol. If the values for the release of $\left[{ }^{3} \mathrm{H}\right]$ cholesterol by the cyclodextrin alone are subtracted from the values for release in the serum/LUV/2OH $\beta \mathrm{CD}$ mixture, it is apparent that a cholesterol shuttle function is present below $1 \mathrm{mM} 2 \mathrm{OH} \beta \mathrm{CD}$, and above this concentration the cyclodextrin also contributes to efflux by acting as an acceptor. Fig. $3 \mathrm{~B}$ illustrates the free cholesterol content of $\mathbf{J} 774$ cells after incubation with $2 \mathrm{OH} \beta \mathrm{CD}$, alone or in combination with serum and LUV. Consistent with the isotopic data (Fig. $3 \mathrm{~A}$ ), there was no change in cell cholesterol content if the $2 \mathrm{OH} \beta \mathrm{CD}$ was added to the culture medium alone, whereas there was a progressive reduction in cell free cholesterol content when increasing concentrations of the cyclodextrin were added in combination with the serum/LUV mixture.

Shuttle efficiency of various cyclodextrins. We (8) and others $(27,28)$ have previously shown that the ability of cyclodextrins to solubilize guest molecules such as cholesterol is greatly influenced by the structure of the cyclodextrin host. To determine if the shuttle effect of cyclodextrins was a function of cyclodextrin structure, we compared the efflux of labeled cell cholesterol to different cyclodextrins when added to the incubation medium for $2 \mathrm{~h}$ at concentrations of 1.0 and $0.1 \mathrm{mM}$. As shown in Fig. 4, the cyclodextrins differed in efflux efficiency in the order methyl- $\beta$-cyclodextrin $>\beta$-cyclodextrin $(\beta C D)>$ $2 \mathrm{OH} \beta \mathrm{CD}>$ carboxymethyl- $\beta$-cyclodextrin $>$ tetradecasulfated- $\beta$-cyclodextrin. Comparative dose-response curves assaying the shuttling efficiency of methyl- $\beta$-cyclodextrin to $2 \mathrm{OH} \beta \mathrm{CD}$ and analysis of the results as was performed in Fig. $3 A$ revealed that, at concentrations $>0.1 \mathrm{mM}$, methylcyclodextrin exhibited the ability to act as a cholesterol sink while, at concentrations $<0.1 \mathrm{mM}$, it exhibited only the shuttle effect (data not shown). This value compares to a concentration of $1.0 \mathrm{mM}$ for $2 \mathrm{OH} \beta \mathrm{CD}$ (see Fig. $3 A$ ).

Effect of LUV concentration on cyclodextrin-mediated cholesterol efflux. In the studies presented above, we have used a single concentration of LUV $(1 \mathrm{mg} / \mathrm{ml})$ to serve as a cholesterol sink and thus to shift the cell medium cholesterol gradient. The data presented in Fig. $5 A$ illustrate the changes in efflux of labeled cholesterol and cell cholesterol mass when free cholesterol-enriched J774 macrophages were incubated in 5\% human serum supplemented with a constant concentration of $2 \mathrm{OH} \beta \mathrm{CD}(1 \mathrm{mM})$ and increasing concentrations of LUV. As anticipated, there is a reciprocal relationship between appearance of labeled cholesterol in the medium and the reduction of cell cholesterol mass. The greatest effect of the addition of LUV occurs at concentrations $<1 \mathrm{mg}$ phospholipid/ml, with less dramatic changes up to $\sim 10 \mathrm{mg}$ phospholipid/ml. Fig. $5 B$ presents efflux data when increasing concentrations of LUV were added either to serum alone, $2 \mathrm{OH} \beta \mathrm{CD}(1 \mathrm{mM})$ alone, or to the serum/cyclodextrin mixture. The combination of cyclodextrin and LUV produced substantial efflux in the absence of any serum components. In a separate study (data not shown),
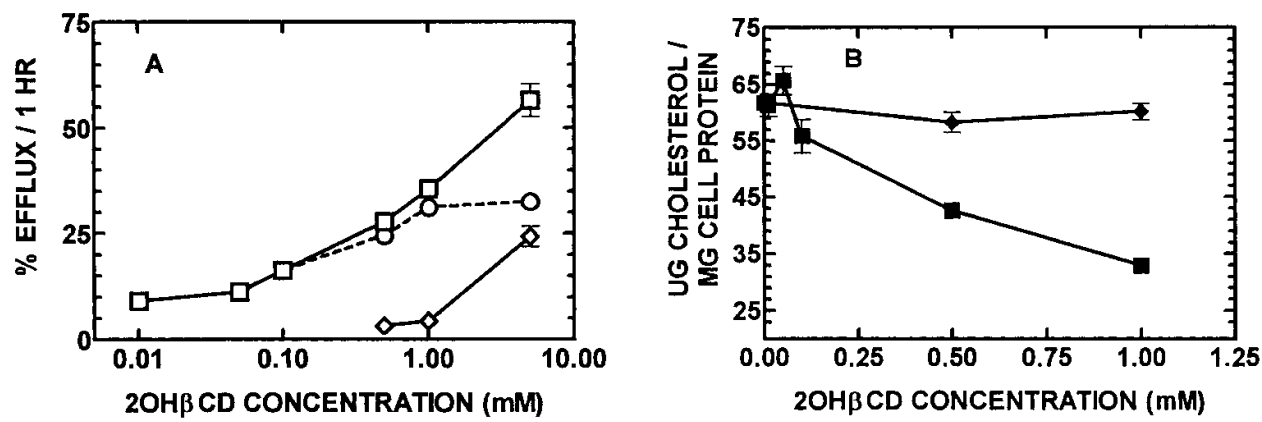

Figure 3. Effect of $2 \mathrm{OH} \beta \mathrm{CD}$ concentration on the efflux of cholesterol from J774 cells. Monolayers of J774 cells were grown, labeled with $\left[{ }^{3} \mathrm{H}\right]$ cholesterol and enriched with free cholesterol as described in Fig. 1. (A) The fractional efflux of labeled cholesterol was determined after a 1-h incubation of the monolayers with a combination of $5 \% \mathrm{hu}-$ man serum, LUV at $1 \mathrm{mg} / \mathrm{ml}$ phospholipid, and the indicated amount of $2 \mathrm{OH} \beta \mathrm{CD}(\square)$ or the $2 \mathrm{OH} \beta \mathrm{CD}$

alone $(\diamond)$. The calculated shuttle effect $(\bigcirc$, dotted line $)$ of the $2 \mathrm{OH} \beta C D$ was established by subtracting the efflux obtained with the $2 \mathrm{OH} \beta C D$ alone from the efflux value of the mixture of HS, LUV, and 2OH $\beta C D$. (B) The cholesterol content of the cells after a 6-h incubation with either the $2 \mathrm{OH} \beta \mathrm{CD}$ alone $(\bullet)$ or with the mixture of HS, LUV, and $2 \mathrm{OH} \beta \mathrm{CD}(\boldsymbol{\square})$. 


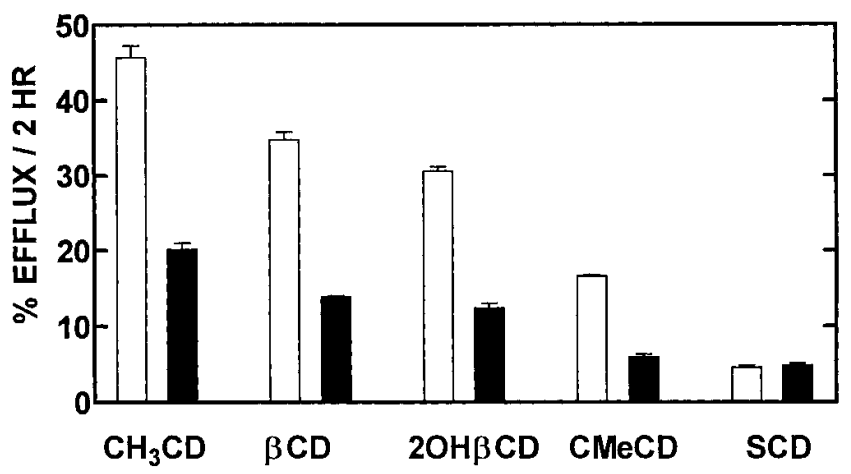

Figure 4. Ability of different cyclodextrins to stimulate the efflux of radiolabeled cholesterol from free cholesterol-enriched $\mathrm{J} 774$ cells. Open bars, $1.0 \mathrm{mM}$; closed bars, $0.1 \mathrm{mM}$. $\mathrm{CH}_{3} \mathrm{CD}$, methyl- $\beta$-cyclodextrin; $\beta \mathrm{CD}, \beta$-cyclodextrin; $\mathrm{CMeCD}$, carboxymethyl- $\beta$-cyclodextrin; SCD, tetradecasulfated- $\beta$-cyclodextrin. Efflux to $5 \%$ serum alone was $4.4 \%$. Values are the average and SD of triplicate determinations.

we determined that the phospholipid effect on the efflux of cell cholesterol label and mass was similar with LUV composed of either 1-palmitoyl-2-oleoyl phosphatidylcholine or soy phosphatidylcholine. In addition, small unilamellar vesicles could be substituted for the LUV. These effects are not specific to macrophages because in studies with Fu5AH hepatoma cells, HDL particles or cyclodextrin were found to be able to shuttle cell cholesterol to LUV (29).

Cyclodextrin-mediated free and esterified cholesterol clearance from foam cells. The experiments reported above were conducted with cells enriched with free cholesterol. Within the atherosclerotic plaque, macrophage-derived foam cells accu-
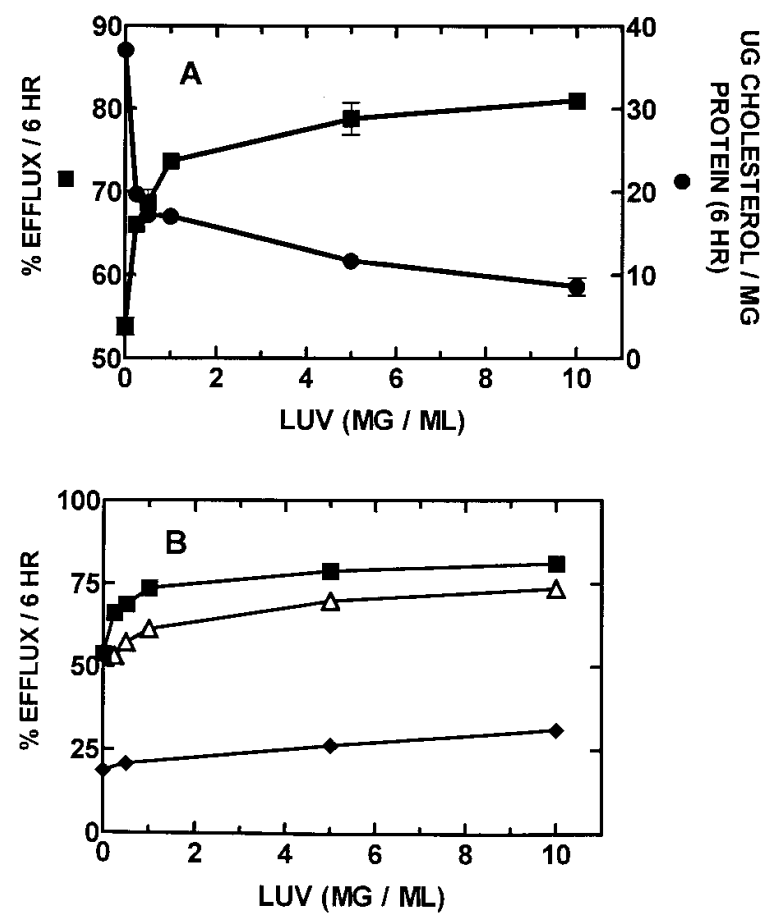

Figure 5. Effect of LUV concentration on the efflux of cholesterol from free cholesterol-enriched $\mathbf{J} 774$ cells. $(A)$ Cells were incubated for $6 \mathrm{~h}$ in medium supplemented with $5 \%$ human serum, $1.0 \mathrm{mM}$ $2 \mathrm{OH} \beta \mathrm{CD}$, and increasing concentrations of LUV. $\mathbf{a}$, percent efflux of $\left[{ }^{3} \mathrm{H}\right]$ cholesterol; $\bullet$, cell cholesterol mass as determined by gas-liquid chromatography. $(B)$ Cells were incubated in $5 \%$ serum plus indicated concentrations of LUV $(\checkmark) ; 1.0 \mathrm{mM} 2 \mathrm{OH} \beta C D$ plus LUV in the absence of serum $(\Delta)$, or $5 \%$ serum plus $1.0 \mathrm{mM} 2 \mathrm{OH} \beta \mathrm{CD}$ and the indicated concentration of LUV ( $\mathbf{\square}$, as in $A)$, and the percentage of radioactive cholesterol was determined. Average and SD of triplicate determinations (error bars within symbols if not indicated).
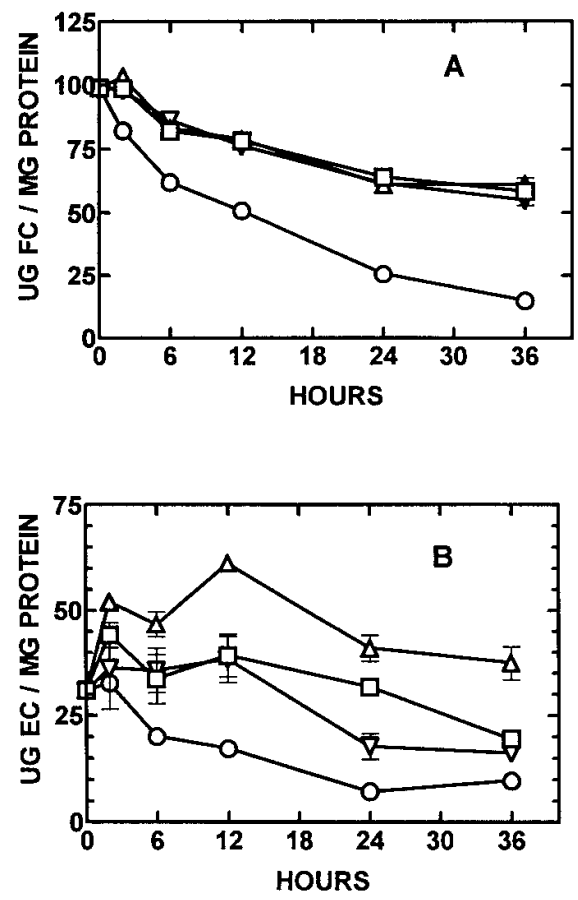
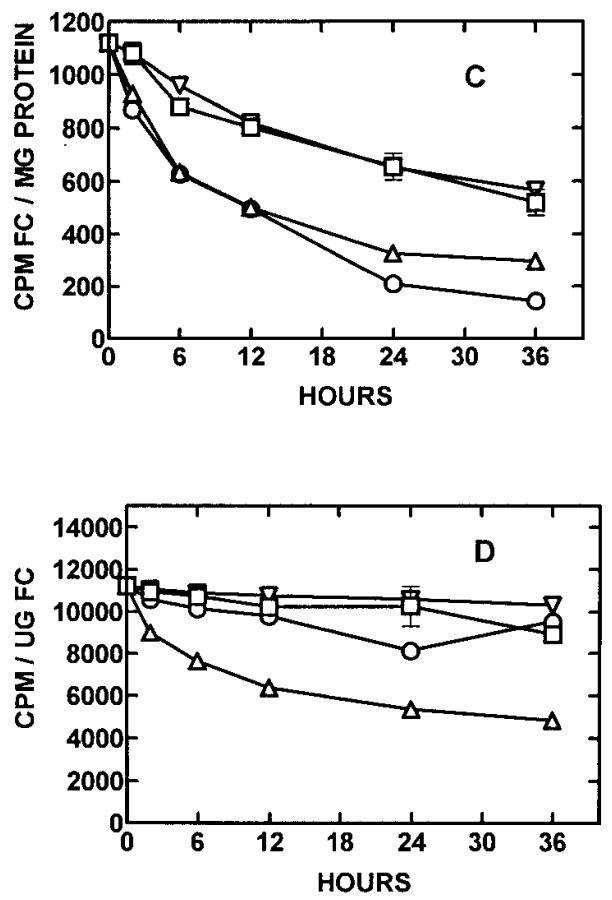

Figure 6. Cholesterol flux from elicited mouse peritoneal macrophages enriched with both free and esterified cholesterol. Cells were exposed to $5 \%$ human serum alone $(\square)$ or serum-containing medium supplemented with $1 \mathrm{mg} / \mathrm{ml} \mathrm{LUV}$ $(\nabla), 1 \mathrm{mM} 2 \mathrm{OH} \beta \mathrm{CD}(\Delta)$, or LUV plus $2 \mathrm{OH} \beta \mathrm{CD}(\bigcirc)$. $(A)$ The mass of cell free cholesterol $(F C)$. (B) The mass of cell esterified cholesterol $(E C)$. (C) The cellular concentration of $\left[{ }^{3} \mathrm{H}\right]$-free cholesterol. $(D)$

The specific activities of the cellular $\left[{ }^{3} \mathrm{H}\right]$-free cholesterol. Values are the averages and SD of triplicate determinations. 
mulate cholesterol in both the free and ester pools. Therefore, we next determined the effect of cyclodextrin and LUV on the metabolism of cholesterol in elicited mouse peritoneal macrophages enriched in both free and esterified cholesterol. Exposure of these macrophages for $36 \mathrm{~h}$ to $5 \%$ human serum alone or supplemented with either LUV or $2 \mathrm{OH} \beta \mathrm{CD}$ produced only modest decreases in cell cholesterol content, whereas the exposure of the macrophages to the combination of serum, LUV and $2 \mathrm{OH} \beta \mathrm{CD}$ was the only treatment that produced an accelerated decrease in the mass of free and esterified cellular cholesterol (Fig. 6, $A$ and $B$ ). Fig. $6 C$ shows the increased loss of radiolabeled cholesterol from the cells during the $36 \mathrm{~h}$ incubation when the medium contained the $2 \mathrm{OH} \beta \mathrm{CD}$, either alone or together with LUV. However, as illustrated in Fig. $6 D$, there was a dramatic reduction in the specific activity of the cell free cholesterol only in the system in which cells were incubated with serum and $2 \mathrm{OH} \beta C D$. This accentuated reduction in cell free cholesterol-specific activity in the presence of cyclodextrin further demonstrates that the cyclodextrin is enhancing the bidirectional flux of cholesterol between cells and serum lipoproteins, and that the addition of the LUV to the system reduces the influx component of the bidirectional flux.

\section{Discussion}

The movement of cholesterol out of the plasma membrane to extracellular acceptors represents the first step in the process of reverse cholesterol transport (for reviews see references 1 , 2 ). It is now generally accepted that this reaction involves the desorption of membrane cholesterol into the aqueous phase followed by the incorporation of the molecule into the acceptor particle (2). Although this aqueous diffusion step does not appear to require specific membrane receptors, there is evidence that the interaction of physiological acceptors such as HDL with the plasma membrane may modulate some pathways involved in intracellular cholesterol transport $(3,4)$.

The entire process of reverse cholesterol transport requires a wide array of lipoprotein particles and related proteins such as lipases, LCAT, and cholesteryl ester transfer protein. A number of different particles are candidate acceptors for cell cholesterol efflux and it can be proposed that some may act as cholesterol shuttles, whereas other particles function as cholesterol sinks. The development of this shuttle/sink model has benefited from a number of recent studies on the efflux of cell cholesterol to serum. Short-term incubations (1-5 min) using high concentrations of serum or plasma emphasize the importance of small particles, such as pre $\beta$-HDL $(5,30)$ and lipidfree apoproteins $(15,31)$, as the initial acceptors of cell cholesterol, indicating a shuttle role for these acceptors. On the other hand, experiments using longer incubation times and more dilute sera have demonstrated the importance of phospholipids, particularly HDL phospholipid, in modulating cholesterol efflux $(24,26,32)$; these measurements reflect the sink capacity of serum.

The ideal cholesterol shuttle would be a high efficiency, low capacity particle that serves to move cholesterol out of the cell membrane and deliver it to particles acting as cholesterol sinks. These latter lipoproteins can be expected to be low efficiency, high capacity acceptors that could solubilize large amounts of cell cholesterol and prevent the exchange of the

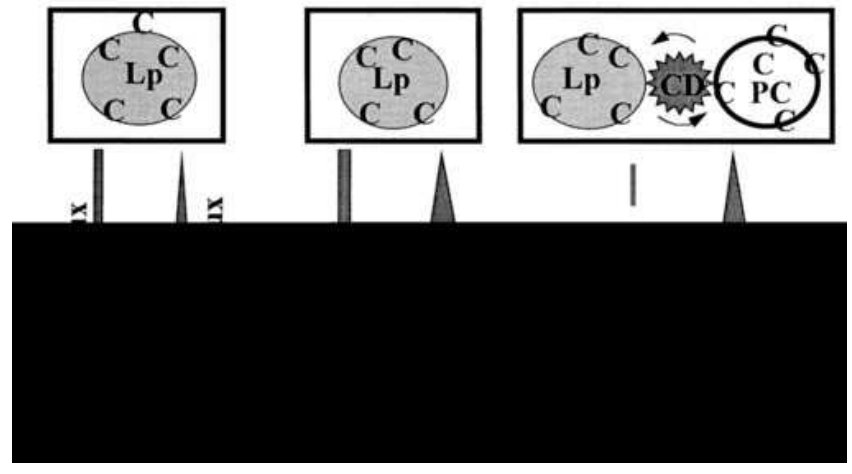

Figure 7. The shuttle and sink model for cellular cholesterol efflux. $(A)$ The movement of cholesterol molecules between the cell plasma membrane and a lipoprotein such as HDL is a bidirectional process with influx and efflux being separate processes. Under many conditions, free cholesterol in the membrane is in equilibrium with free cholesterol in the lipoproteins, thus there is turnover of cholesterol molecules without changes in cholesterol mass in either the cell or medium compartments. When low concentrations of cyclodextrins are added to the serum $(B)$, the rates of influx and efflux are increased, but the equilibrium is not changed. Thus, cholesterol molecules turnover at a faster rate but there is no net change in cholesterol content in the cell and medium compartments. When both phospholipid $(P C)$ vesicles and cyclodextrins are added to the medium $(C)$, the vesicles act as a sink for extracellular cholesterol, thus shifting the equilibrium to favor net efflux. See Discussion for more details.

free cholesterol back into the cell plasma membrane. Thus, the requirement for a shuttle molecule would be easy access to the cell plasma membrane and a high cholesterol on/off rate, while the requirement for a sink would be a particle having a slow cholesterol off rate. In vivo, the retention of cholesterol in the sink would be enhanced by the conversion of free cholesterol to cholesteryl ester through the action of LCAT.

The potential catalytic/shuttle effect of cyclodextrin for lipid transport was discussed by Irie et al. (33), who suggested that the coupling of cyclodextrins with lipid emulsions could enhance lipid transport. Our results have validated the "shuttle-sink" model for cell cholesterol flux, presented in Fig. 7, by demonstrating that at relatively low concentrations $(<1.0$ $\mathrm{mM}) 2 \mathrm{OH} \beta \mathrm{CD}$ acts catalytically to increase the exchange of cholesterol molecules between cell membranes and serum lipoproteins without changing the cell/medium equilibrium. The high efficiency of the cyclodextrin is probably a function of its small size, which allows large numbers of cyclodextrin molecules to directly approach the plasma membrane. We have previously proposed that the location of cyclodextrin molecules near the surface of the cell allows the cholesterol in the membrane to desorb directly into the hydrophobic core of the cyclodextrin without entering into the aqueous phase (9). This direct incorporation of membrane cholesterol into the cyclodextrin reduces the activation energy for cholesterol efflux from the $\sim 20 \mathrm{kcal} / \mathrm{mol}$ required for movement of membrane cholesterol to phospholipid-containing acceptors, to $\sim 7 \mathrm{kcal} /$ mol for cyclodextrins (9). Since in the case of J774 macrophages, the cells and medium are apparently at equilibrium, the addition of cyclodextrin to the serum results in extensive turnover of cholesterol without significant change in cell cholesterol mass. The equilibrium conditions can be shifted to fa- 
vor the medium through the addition of phospholipids to act as a cholesterol sink, in this study in the form of LUV. The addition of LUV to serum has relatively little effect on the rate of movement of cholesterol molecules since, as previously shown, such large phospholipid vesicles are inefficient mediators of cell cholesterol efflux (11). Whereas neither LUV nor cyclodextrin alone stimulated cell cholesterol depletion, the combination of the cyclodextrin shuttle together with the LUV sink produced a dramatic effect on cholesterol flux and net cholesterol movement. As shown in Fig. 3, cyclodextrins can function as both shuttles and sinks. At concentrations of $2 \mathrm{OH} \beta \mathrm{CD} \leq 1$ $\mathrm{mM}$, the cyclodextrin alone did not have the capacity to produce efflux but could catalyze the exchange of cholesterol between cells and serum lipoproteins. Above $1 \mathrm{mM}$, there is sufficient cyclodextrin in the medium to serve as both a shuttle and a sink. As demonstrated in Fig. 5 B, the efflux of cell cholesterol to medium lacking serum, but supplemented with cyclodextrin and LUV, is very substantial and represents 80 $90 \%$ of the efflux observed when $5 \%$ serum is present with the cyclodextrin and LUV. Thus, the phospholipid supplied by the LUV is more than sufficient to act as a sink and shift the equilibrium cholesterol distribution. The fact that efflux occurs in this simple experimental system further validates the shuttle/ sink model for cholesterol efflux. The net movement of free cholesterol from cells to medium can promote the net hydrolysis and clearance of cholesteryl ester stored in these model foam cells, and this response is observed with both the J774 macrophage cell line (data not shown) and mouse peritoneal macrophages (Fig. 6). In addition, the data presented in Fig. 6, particularly the free cholesterol-specific activity data in Fig. 6 $D$, reemphasizes the fact that the cyclodextrin acts as a catalyst and stimulates both influx and efflux in the system lacking the LUV sink.

At present, it is not known whether the rate-limiting step in the efflux of cholesterol in peripheral tissues is the level of shuttlelike HDL or of lipoproteins functioning as sinks. Quantitative and qualitative information on the shuttle and sink roles of serum lipoproteins would be very useful for future efforts to increase reverse cholesterol transport. Since pharmacological and metabolic attempts to raise HDL levels have been relatively unsuccessful, other approaches have been initiated to mobilize cholesterol out of the atherosclerotic lesions and transport it to the liver. These studies have focused on the intravascular administration of phospholipid vesicles (10), lipid-free apo AI (34), recombinant particles made with apo AI and phospholipid $(35,36)$, or native HDL (37). A number of these treatments have demonstrated clearance of vessel wall cholesterol and reductions of atherosclerotic plaque $(34,37)$. It is possible that short-term treatment could be used to mobilize the cholesterol out of lipid-rich lesions, with the resultant stabilization of the plaque (38). It is in this context that cyclodextrins, or related compounds (39), might be pharmacologically useful. In this study, we have used $2 \mathrm{OH} \beta \mathrm{CD}$ as the shuttle molecule; however, we have also demonstrated that other cyclodextrins can be even more efficient (Fig. 4). Thus, manipulation of cyclodextrin structure could result in compounds that serve as effective shuttles at lower concentration, and are retained in the circulation for longer periods of time. Based on our present study, the use of cyclodextrins together with phospholipid vesicles would be expected to enhance the clearance of vessel wall cholesterol to a greater extent than has been obtained with either cyclodextrins or LUV alone.

\section{Acknowledgments}

This work was supported in part by Program Project grant HL22633, a Minority Investigator Research Supplement (MIRS) grant from the National Institutes of Health (M. de la Llera Moya), a Mentored Research Scientist Development Award for Minority Faculty, HL03522 (M. de la Llera Moya), a North Atlantic Treaty Organization Collaborative Research Grant, 930317 (V. Atger), an Allegheny-Singer Research Institute grant, 95-045-3MCP (G. Rothblat), and an International Research Fellowship from the Heart and Stroke Foundation of British Columbia and Yukon to W. Rodrigueza.

\section{References}

1. Fielding, C.J., and P.E. Fielding. 1995. Molecular physiology of reverse cholesterol transport. J. Lipid Res. 36:211-228.

2. Johnson, W.J., F.H. Mahlberg, G.H. Rothblat, and M.C. Phillips. 1991. Cholesterol transport between cells and high density lipoproteins. Biochim. Biophys. Acta. 1085:273-298.

3. Rothblat, G.H., F.H. Mahlberg, W.J. Johnson, and M.C. Phillips. 1992. Apolipoprotein, membrane cholesterol domains, and the regulation of cholesterol efflux. J. Lipid Res. 33:1091-1098.

4. Oram, J.F. 1990. Cholesterol trafficking in cells. Curr. Opin. Lipidol. 1: 416-421.

5. Francone, O.L., and C.J. Fielding. 1990. Initial steps in reverse cholesterol transport: the role of short-lived cholesterol acceptors. Eur. Heart J. 11: 218-224.

6. de la Llera Moya, M., V. Atger, J.L. Paul, N. Fournier, N. Moatti, P. Giral, K.E. Friday, and G.H. Rothblat. 1994. A cell culture system for screening human serum for ability to promote cellular cholesterol efflux: relationships between serum components and efflux, esterification and transfer. Arterioscler. Thromb. 14:1056-1065.

7. Pitha, J., T. Irie, P.B. Sklar, and J.S. Nye. 1988. Drug solubilizers to aid pharmacologists: amorphous cyclodextrin derivatives. Life Sci. 43:493-502.

8. Kilsdonk, E.P.C., P. Yancey, G. Stoudt, F.W. Bangerter, W.J. Johnson, M.C. Phillips, and G.H. Rothblat. 1995. Cellular cholesterol efflux mediated by cyclodextrins. J. Biol. Chem. 270:17250-17256.

9. Yancey, P.G., W.V. Rodrigueza, E.P.C. Kilsdonk, G.W. Stoudt, W.J. Johnson, M.C. Phillips, and G.H. Rothblat. 1996. Cellular cholesterol efflux mediated by cyclodextrins: demonstration of kinetic pools and mechanism of efflux. J. Biol. Chem. 271:16026-16034.

10. Rodrigueza, W.V., P.H. Pritchard, and M.J. Hope. 1993. The influence of size and composition of the cholesterol mobilizing properties of liposomes in vivo. Biochim. Biophys. Acta. 1153:9-19.

11. Davidson, W.S., W.V. Rodrigueza, S. Lund-Katz, W.J. Johnson, G.H. Rothblat, and M.C. Phillips. 1995. Effects of acceptor particle size on the efflux of cellular free cholesterol. J. Biol. Chem. 270:17106-17113.

12. Bernard, D.W., A. Rodriguez, G.H. Rothblat, and J.M. Glick. 1991. cAMP stimulates cholesteryl ester clearance to high density lipoproteins in J774 macrophages. J. Biol. Chem. 266:710-716.

13. Warner, G.J., G. Stoudt, M. Bamberger, W.J. Johnson, and G.H. Rothblat. 1995. Cell toxicity induced by inhibition of acyl coenzyme A cholesterol acyltransferase and accumulation of unesterified cholesterol. J. Biol. Chem. 270:5772-5778.

14. Ross, A.C., K. Go, J. Heider, and G.H. Rothblat. 1984. Selective inhibition of acylCoA:cholesterol acyltransferase by compound 58-035. J. Biol. Chem. 258:815-819.

15. Yancey, P.G., J.K. Bielicki, W.J. Johnson, S. Lund-Katz, M.N. Palgunachari, G.M. Anantharamaiah, J.P. Segrest, M.C. Phillips, and G.H. Rothblat. 1995. The efflux of cellular cholesterol and phospholipid to lipid-free apolipoproteins and class A amphipathic peptides. Biochemistry. 34:7955-7965.

16. Fedoroff, S. 1958. Effect of human blood serum on tissue cultures. I. Some properties and specificity of toxic human serum, and its interaction with strain L cells. Tex. Rep. Biol. Med. 16:31-47.

17. Fedoroff, S., and J. Doerr. 1962. Effect of human blood serum on tissue cultures. III. A natural cytotoxic system in human blood serum. J. Natl. Cancer Inst. 29:331-347.

18. Ishikawa, T.T., J. MacGee, J.A. Morrison, and C.J. Glueck. 1974. Quantitative analysis of cholesterol in 5 to $20 \mu \mathrm{l}$ of plasma. J. Lipid Res. 15:286-291.

19. Klansek, J., P. Yancey, R.W. St. Clair, R.T. Fischer, W.J. Johnson, and J.M. Glick. 1995. Cholesterol quantitation by GLC: artifactual formation of short-chain steryl esters. J. Lipid Res. 36:2261-2266.

20. Markwell, M.A.K., S.M. Haas, L.L. Bieber, and N.E. Tolbert. 1978. A modification of the Lowry procedure to simplify protein determination in membrane and lipoprotein samples. Anal. Biochem. 87:206-210.

21. Johnson, W.J., M.J. Bamberger, R.A. Latta, P.E. Rapp, M.C. Phillips, and G.H. Rothblat. 1986. The bidirectional flux of cholesterol between cells and lipoproteins. J. Biol. Chem. 261:5766-5776.

22. Bernard, D.W., A. Rodriguez, G.H. Rothblat, and J.M. Glick. 1990. In- 
fluence of high density lipoprotein on esterified cholesterol stores in macrophages and hepatoma cells. Arteriosclerosis. 10:135-144.

23. Johnson, W.J., F.H. Mahlberg, G.K. Chacko, M.C. Phillips, and G.H. Rothblat. 1988. The influence of cellular and lipoprotein cholesterol contents on the flux of cholesterol between fibroblasts and high density lipoprotein. $J$. Biol. Chem. 263:14099-14106.

24. Fournier, N., M. de la Llera Moya, B. Burkey, J. Swaney, J.J. Paterniti, N. Moatti, V. Atger, and G.H. Rothblat. 1996. The role of HDL phospholipids in efflux of cell cholesterol to whole serum: studies with human apo AI transgenic rats. J. Lipid Res. 37:1704-1711.

25. Sloop, C.H., L. Dory, and P.S. Roheim. 1987. Interstitial fluid lipoproteins. J. Lipid Res. 28:225-237.

26. Atger, V., M. de la Llera Moya, M. Bamberger, O. Francone, P. Casgrove, A. Tall, A. Walsh, N. Moatti, and G. Rothblat. 1995. Cholesterol efflux potential of sera from mice expressing human CETP and/or human apolipoprotein AI. J. Clin. Invest. 96:2613-2622.

27. Irie, T., K. Fukunaga, and J. Pitha. 1992. Hydroxypropylcyclodextrins in parenteral use. I: lipid dissolution and effects on lipid transfers in vitro. $J$. Pharm. Sci. 81:521-523.

28. Rajewski, R.A., G. Traiger, J. Breshnahan, P. Jaberaboansari, V.J. Stella, and D.O. Thompson. 1995. Preliminary safety evaluation of parenterally administered sylfoalkyl ether $\beta$-cyclodextrin derivatives. J. Pharm. Sci. 84:927932.

29. Rodrigueza, W.V., K.J. Williams, G.H. Rothblat, and M.C. Phillips. 1997. Remodeling and shuttling: mechanisms for the synergistic effects between different acceptor particles in the mobilization of cellular cholesterol. Arterioscler. Thromb. Vasc. Biol. 17:383-393.

30. Castro, G.R., and C.J. Fielding. 1988. Early incorporation of cellderived cholesterol into pre- $\beta$-migrating high-density lipoprotein. Biochemis- try. 27:25-29.

31. Hara, H., and S. Yokoyama. 1992. Role of apolipoproteins in cholesterol efflux from macrophages to lipid microemulsion: proposal of a putative model for the pre- $\beta$ high-density lipoprotein pathway. Biochemistry. 31:20402046.

32. Jonas, A., K. Bottum, N. Theret, P. Duchateau, and G. Castro. 1994 Transfer of cholesterol from Ob1771 cells or LDL to reconstituted, defined high density lipoproteins. J. Lipid Res. 35:860-870.

33. Irie, T., K. Fukunaga, M.K. Garwood, T.O. Carpenter, and J. Pitha 1992. Hydroxypropylcyclodextrins in parenteral use. II: effects on transport and disposition of lipids in rabbit and humans. J. Pharm. Sci. 81:524-528.

34. Miyazaki, A., S. Sakuma, W. Morikawa, T. Takiue, F. Miake, T. Terano, M. Sakai, H. Hakamata, Y. Sakamoto, M. Naito, et al. 1995. Intravenous injection of rabbit apolipoprotein A-I inhibits the progression of atherosclerosis in cholesterol-fed rabbits. Arterioscler. Thromb. Vasc. Biol. 15:1882-1888.

35. Sirtori, C.R. 1995. Recombinant apolipoproteins come of age. Nutr. Metab. Cardiovasc. Dis. 5:81-83.

36. Carlson, L.A. 1995. Effect of a single infusion of recombinant human proapolipoprotein A-I liposomes (synthetic HDL) on plasma lipoproteins in patients with low high density lipoprotein cholesterol. Nutr. Metab. Cardiovasc. Dis. 5:85-91.

37. Badimon, J.J., L. Badimon, A. Galvez, R. Dische, and V. Fuster. 1989. High density lipoprotein plasma fractions inhibit aortic fatty streaks in cholesterol-fed rabbits. Lab. Invest. 60:455-461.

38. Brown, B.G., X. Zhao, D.E. Sacco, and J.J. Albers. 1993. Lipid lowering and plaque regression. New insights into prevention of plaque disruption and clinical events in coronary disease. Circulation. 87:1781-1791.

39. Diederich, F., and B. Peterson. 1994. Dissolution of cholesterol in water by a synthetic receptor. Angew. Chemie. Int. Ed. Engl. 33:1625. 